\title{
STRUCTURAL ASPECTS OF RAILWAY TRUSS BRIDGES AFFECTING TRANSVERSE SHEAR FORCES IN STEEL-CONCRETE COMPOSITE DECKS
}

\author{
Wojciech SIEKIERSKI ${ }^{1}$ \\ Poznan University of Technology, Institute of Structural Engineering, Poland
}

\begin{abstract}
At the steel-concrete interface, the horizontal shear forces that are transverse to cross beams occur due to joint action of the steel-concrete composite deck and the truss girders. Numerical analysis showed that values of the forces are big in comparison to the longitudinal shear forces. In both cases extreme force values occur near side edges of a slab. The paper studies possibilities of reduction of these shear forces by structural alterations of the following: rigidity of a concrete slab, arrangement of a wind bracing, arrangement of concrete slab expansion joints. An existing railway truss bridge span has been analysed. Numerical analysis shows that it is possible to reduce the values of shear forces transverse to cross beams. It may reach $20 \%$ near the side edges of slabs and $23 \%$ in the centre of slab width.
\end{abstract}

Keywords: steel-concrete composite deck, shear force, truss bridge span

\section{STEEL-CONCRETE COMPOSITE DECKS OF RAILWAY THROUGH BRIDGES}

Railway through bridges are bridges with deck situated between main girders usually arches or trusses (in case of trusses deck is connected to their bottom flanges). For high-speed railway transport such bridges often have steel-concrete composite decks $[2,8]$. For such railway bridges four types of structural forms of composite decks are distinguished [2]:

\footnotetext{
${ }^{1}$ Corresponding author: Poznan University of Technology, Institute of Structural Engineering, Faculty of Civil and Environmental Engineering, Piotrowo 5, 60-965 Poznan, Poland, e-mail: Wojciech.siekierski@put.poznan.pl, tel.48616475834
} 
- concrete slab composited with steel deck system and bottom flanges of the main trusses,

- concrete slab composited with bottom flanges of the main trusses only at nodes,

- steel longitudinal and transverse girders composited with concrete slab,

- orthotropic integral steel deck composited with concrete slab.

In the case of narrow bridges, such as single track railway bridges, longitudinal beams are not necessary. Composite deck is created out of cross beams and concrete slab [5] - Fig. 1. Block shear connectors or studs are used (Fig. 2). Bridge spans of $\mathrm{L}_{\mathrm{t}}>30 \mathrm{~m}$ have the deck slab usually divided across into two or three parts. The expansion joints reduce slab tension due to thermal effects and joint action of deck and girders. They also reduce bending and shear in horizontal plane in cross beams.

Cross beams are connected to truss flanges. In the case of I-shape flanges crosssection cross beams are connected to vertical ribs that stiffen flange webs. The web of each cross beam is connected to the appropriate rib of flange web with pair of steel plates - Fig. 3 .

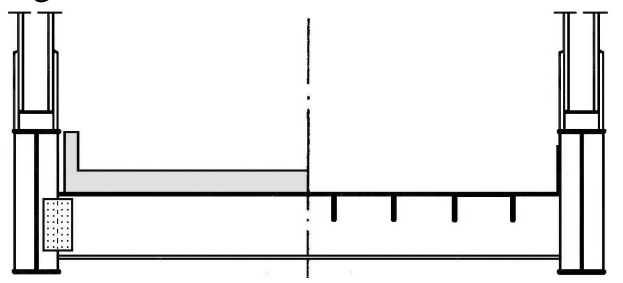

Fig. 1. Decks of contemporary railway truss bridges: steel-concrete composite (left) and orthotropic (right)
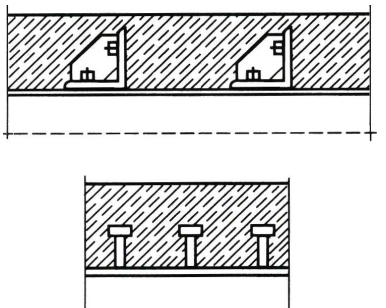

Fig. 2. Examples of shear connectors in steel-concrete composite deck: block connectors (top), studs (bottom)

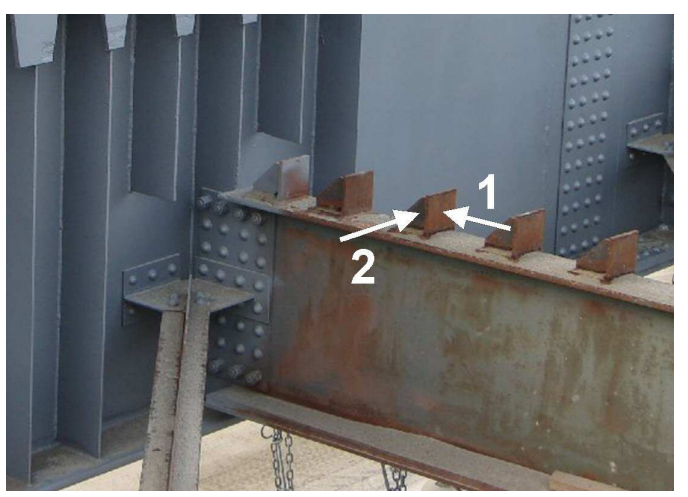

Fig. 3. Cross beam to truss flange connection; concrete slab removed due to refurbishment; longitudinal (1) and transverse (2) shear forces are marked 


\section{TRANSVERSE SHEAR FORCES IN COMPOSITE DECKS DUE TO VERTICAL LOADS}

In the analysis of kind of decks shown in Fig. 1 (left) longitudinal shear forces (Fig. 3, symbol "1") are assigned to cross beam bending while transverse shear forces (Fig. 3, symbol "2") are assigned to shrinkage as well as train braking and acceleration. However transverse shear forces also depend on vertical loads (for example train weight) that imply joint action of deck and girders.

Joint action of two structural members in bending is possible if they are connected in a way that prevents relative horizontal displacement (slip). Methods of analysis of longitudinal shear forces are well recognised and documented [1,3]. Analysis of transverse shear forces cannot be carried out in a similar way because the shear forces at the steel-concrete interface act transversely to cross beams.

The problem may be described in the same way as a traditional arrangement of steel-concrete composite member is considered, i.e. the concrete slab is assumed to be connected to bottom flanges of truss girders by cross beams that act as flexible connectors. Rigidity and load carrying capacity of both the concrete slab and the connection establish the intensity of the joint action of a deck and truss girders. The overall rigidity and load carrying capacity depend on respective parameters of:

- concrete slab - span lengthwise,

- shear connectors between concrete slab and steel cross beams,

- steel cross beams, in horizontal plane,

- connections of cross beams to truss flanges, in horizontal plane.

Horizontal rigidity of a concrete slab along the span depends on the magnitude of tensile stresses in concrete. Uncracked or cracked slab behaviour is possible. In the former case the cross-sectional area of the slab should be considered while in the latter one the cross-sectional area of the main (longitudinal) slab reinforcement must be taken into consideration. Existence of the reinforcement also limits influence of creep and shrinkage of a concrete slab on the transverse shear forces due to joint action of a deck and girders.

To provide a joint action of deck and truss girders shear connectors between concrete slab and steel cross beams have to withstand shear forces transverse to cross beams. In the case of block connectors it is easier to set load carrying capacity. It depends on the side area of the given connectors and their spacing along the cross beams. Load carrying capacity of block connectors depends on their side area and spacing along the cross beam. They may be assumed as being rigid up to their load carrying capacity or up to the load carrying capacity of the adjacent concrete. Stud connectors spacing across cross beams, i.e. in the 
direction of transverse shear, is usually too small to allow for independent behaviour of each one in the row. So each row may be considered as so called multi-stud shear connector. The load carrying capacity of multi-stud shear connectors can not be calculated as multiplication of the load carrying capacity of a single stud times number of studs (additional safety factors must be applied), but rigidity may be taken as such [7].

Top flanges of cross beams are connected to concrete slab that may be assumed as rigid in horizontal plane. Thus cross beam top flanges may be assumed as non deformable in horizontal plane between the outermost stiffeners in comparison with cross beam webs and bottom flanges that may deform in horizontal plane, though to certain extent. It depends on gusset plates of wind bracing that may constrain cross beams webs in midspan and in cross beam connection to truss flange ribs (Fig. 3). Analysis described in [6] shows that extreme stresses in cross beams are likely to occur near end of cross beam in its web just under top flange. They are caused by local bending of the web. Intense stress concentration may occur there leading to brittle fracture of cross beam web [6]. Cross beam webs are connected to vertical ribs of truss bottom flanges with pairs of steel plates (Fig. 3). Horizontal shear forces in steel cross beams are transferred to the connection mainly by cross beam top flanges since, due to their connection to concrete slab, they are the most rigid elements of cross beam section in a horizontal plane. Ribs of truss bottom flanges deform in the horizontal direction according to deformations of compliant cross beam webs. This deformation may be limited by existence of the horizontal gusset plate of wind bracing (Fig. 3). The load carrying capacity of the vertical ribs of truss flange in the horizontal plane may be analysed as rectangular plates fixed along two or three edges.

The results of numerical analysis of the horizontal shear forces in steel-concrete composite deck of the railway truss bridge caused by joint action of deck and girders are presented in [4]. Computations showed that transverse shear forces may reach values comparable with those caused by local bending of cross beams (i.e. longitudinal shear forces). Extreme values of both shear forces (longitudinal and transverse) occurred near cross beam ends. Behaviour of existing structures under service loading does not show any evidence of excess of shear forces at concrete slab to cross beams connection. Nevertheless its load carrying capacity and fatigue strength may be reduced due to combination of shear forces.

Presented discussion on the issues of composite deck behaviour is also applicable to transverse shear forces caused by train braking and acceleration. They are applied to a concrete slab through railway track and gravel as uniformly distributed load. Due to significant in-plane rigidity of the slab and 
similarity of all cross beams it may be assumed that the forces are equally distributed among cross beams. Distribution of transverse shear forces along any particular cross beam depends on flexural rigidity in the horizontal plane and torsional rigidity of the steel part of the beam. Since steel cross beams are weak in horizontal plane the peaks of horizontal shear forces occur near joints, i.e. near girder flanges (near slab side edges) and near wind bracing connections.

\section{FACTORS OF MAGNITUDE OF TRANSVERSE SHEAR FORCES}

It is possible to reduce the magnitude of longitudinal shear forces in regular steel-concrete composite beams by appropriate variations of connector flexibility. The more flexible connector the less shear force it transfers. Increasing connector flexibility towards beam ends equalize shear force distribution along that beam (difference between shear force near the beam end and at midspan becomes smaller).

Magnitude and distribution of transverse shear forces can also be altered. It can be achieved by altering longitudinal rigidity of a concrete slab, rigidity of shear connectors or transverse rigidity of cross beams in a horizontal plane. For the technical reasons the following structural factors are available:

a) rigidity of concrete slab (elastic modulus) and its distribution across the slab (variable thickness),

b) arrangement of wind bracing,

c) arrangement of concrete slab expansion joints.

Numerical analysis has been carried out to establish the extent of influence of the factors mentioned above on the magnitude of transverse shear forces in a composite deck caused by joint action of deck and girders.

\section{ANALYSED STRUCTURE}

Existing railway truss bridge span with steel-concrete composite deck is analysed. It represents several similar railway spans built in Poland over past 40 years. The span is presented in Figs. 4. Characteristics of the members of the main girders and deck are given in Table 1.

Structural dimensions of the span are:

- theoretical length: $51.0 \mathrm{~m}$,

- theoretical height of truss: $8.00 \mathrm{~m}$,

- truss girder spacing: $5.30 \mathrm{~m}$,

- cross beam spacing: $3.19 \mathrm{~m}$, 
- deck slab is made of B35 concrete reinforced with bars of 18G2-b class steel (32ф25 in top and bottom layer); a slab expansion joint is created at a midspan,

- shear connectors are made of the angles with stiffeners.
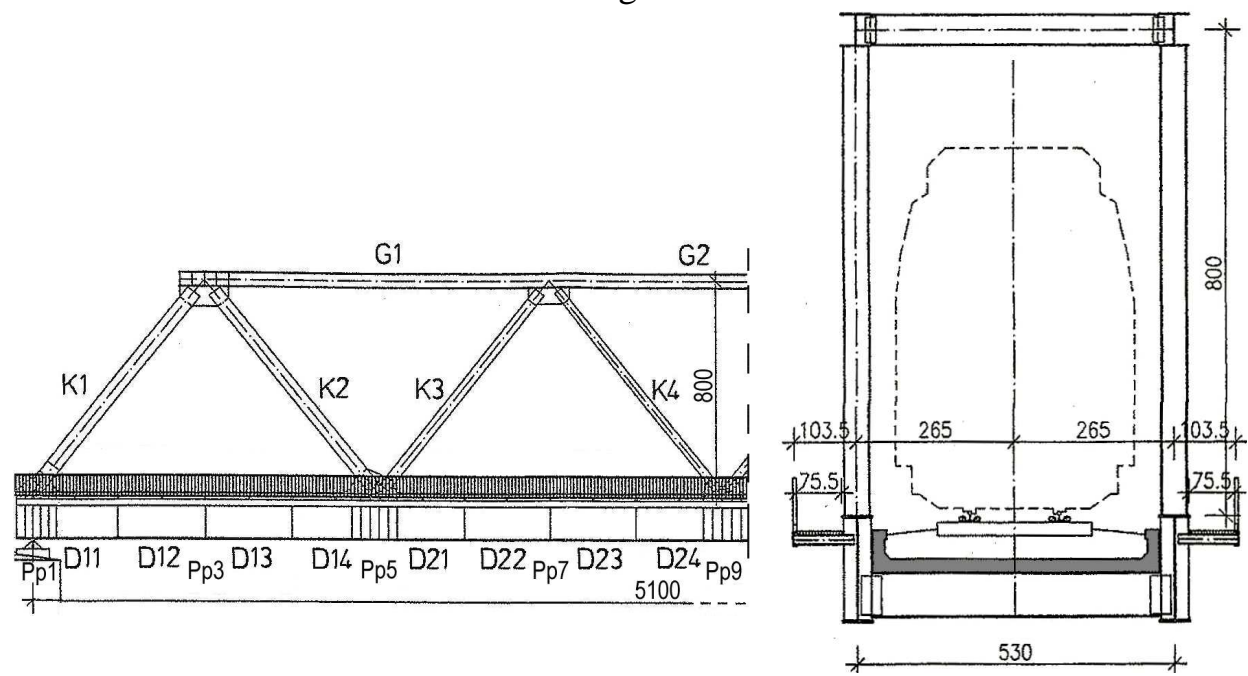

Fig. 4. Elevation (left) and cross section (right) of analysed bridge span

Table 1. Member characteristics

\begin{tabular}{|c|c|c|c|c|}
\hline Model element & $\begin{array}{c}\mathrm{A}_{\mathrm{X}} \\
{\left[\mathrm{cm}^{2}\right]}\end{array}$ & $\begin{array}{c}\mathrm{I}_{\mathrm{X}} \\
{\left[\mathrm{cm}^{4}\right]}\end{array}$ & $\begin{array}{c}\mathrm{I}_{\mathrm{Y}} \\
{\left[\mathrm{cm}^{4}\right]}\end{array}$ & $\begin{array}{c}\mathrm{I}_{\mathrm{Z}} \\
{\left[\mathrm{cm}^{4}\right]}\end{array}$ \\
\hline D11, D12 (a half closer to D11) & 364 & 231 & 1669197 & 33358 \\
\hline $\begin{array}{l}\text { D12 (a half closer to D13), D13, D14 (a half } \\
\text { closer to D13), }\end{array}$ & 394 & 337 & 1878496 & 39608 \\
\hline $\begin{array}{l}\text { D14 (a half closer to D21), D21 (a half closer } \\
\text { to D14) }\end{array}$ & 494 & 1012 & 2586517 & 60441 \\
\hline D21 (a half closer to D22), D22 $\div$ D24 & 474 & 794 & 2466298 & 56274 \\
\hline G1 & 310 & 432 & 158183 & 41711 \\
\hline $\mathrm{G} 2$ & 405 & 958 & 221373 & 58398 \\
\hline K1 (flanges situated vertically) & 244 & 243 & 87208 & 37514 \\
\hline K2 (flanges situated vertically) & 184 & 110 & 59471 & 25014 \\
\hline K3 (flanges situated vertically) & 134 & 58 & 40572 & 12803 \\
\hline K4 (flanges situated vertically) & 98 & 32 & 27393 & 4503 \\
\hline Pp (cross beams - steel plate girder) & 170 & 150 & 157119 & 5439 \\
\hline Wind bracing (top and bottom) & 31 & 9 & 632 & 632 \\
\hline \multicolumn{5}{|c|}{$\begin{array}{l}\text { Concrete slab: width } 4,8 \mathrm{~m} \text {, variable thickness }(24 \div 32 \mathrm{~cm}) \text {, modelled with shell } \\
\text { elements ( } 8 \text { width wise and } 32 \text { lengthwise) }\end{array}$} \\
\hline
\end{tabular}




\section{SCOPE OF NUMERICAL ANALYSIS}

The bridge span described in the previous chapter was test loaded. Displacements of the bottom flange nodes and that of the strains of the bottom flange top fibres were recorded. Then computational model was created out of the beam and the shell element (Fig. 5). Beam elements represent truss members, bracings and cross beams while shell elements represent concrete slab. The model respects true levels of neutral axes of truss bottom flange, cross beams, concrete slab and wind bracing members as well as eccentricity of truss bottom flange in reference to theoretical truss flange axis. Test loading results were used to verify the computational model [4]. The model is shown in Fig. 5. It was crated with an aid of the Autodesk Robot package. Satisfactory results were obtained. Current analysis has been carried out based on the model described in [4]. The only amendment introduced for the current analysis is a variable concrete slab thickness in a span cross-section with 8 shell elements out of which each has an individual thickness.

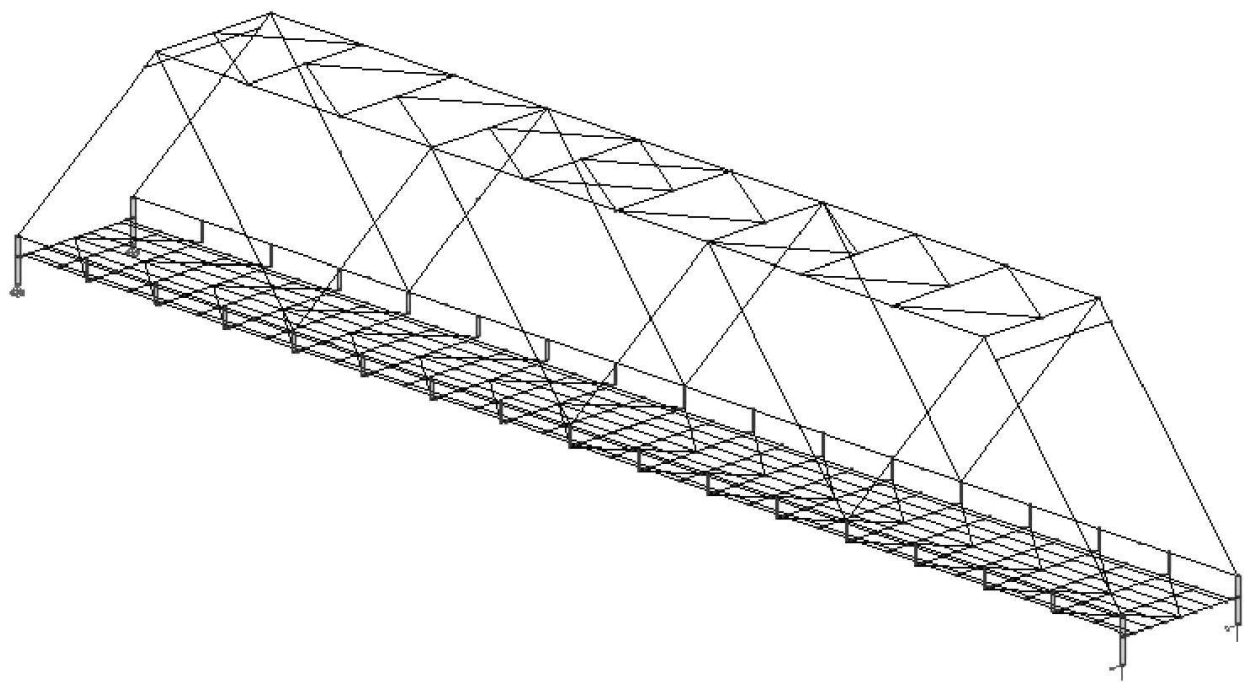

Fig. 5. Computational model of analysed bridge span

Five variations of basic numerical model were analysed. They are:

- model 0 which is the model of existing structure,

- model 1 which regards to an alternative distribution of concrete slab thickness,

- model 2 which regards to an alternative elastic modulus of slab concrete,

- model 3 which regards to an alternative wind bracing arrangement,

- model 4 which regards to additional slab expansion joints. 


\section{Model 1}

In this model distribution of the concrete slab thickness is altered. Drainage system of the deck slab in existing bridge is based on the concept of so called sections i.e. the slab is divided into individually drained parts. Each part has its own inlet pipe in the slab width centre (Fig. 6). Thus the slab is the thickest near side edges and over every second cross beam. Model 1 assumes alternative system: transverse and longitudinal slopes combined and inlet pipes situated near the slab sides. Thus the deck slab is the thinnest near the side edges (near the ends of the cross beams).

a)

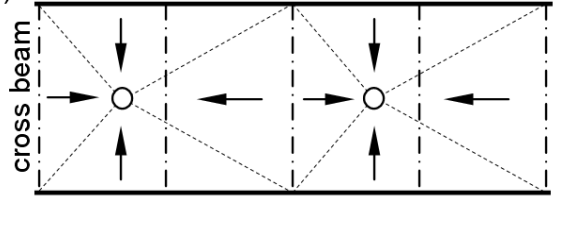

b)

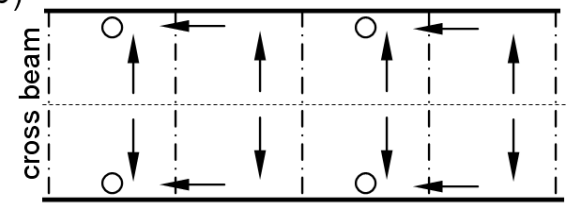

Fig. 6. Existing (a) and alternative (b) drainage system of deck slab

\section{Model 2}

In this model elastic modulus of the concrete slab is altered. It is possible to make the slab out of more or less rigid concrete. Properties of the concrete mix may be altered by lack or presence of certain admixtures. To represent such an alternative $10 \%$ decrease of elastic modulus of concrete is assumed in the model 2.

\section{Model 3}

In this model arrangement of the bottom wind bracing is altered. Wind bracing of the existing structure has so called " $\mathrm{K}$ " layout. Model 3 considers an alternative, "double X", layout. For both layouts, which are shown in Fig. 7 , the same bracing cross-section was used (pair of angles).

a)

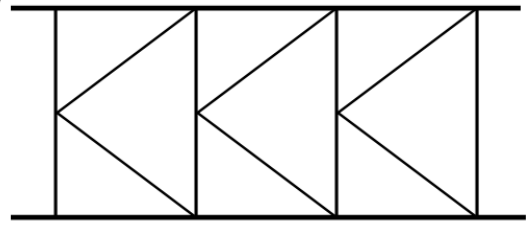

b)

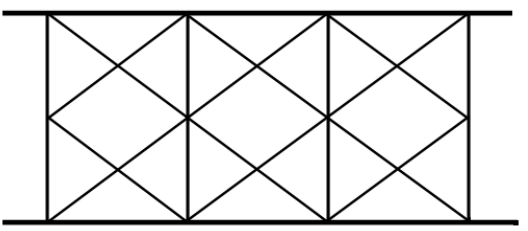

Fig. 7. Existing (a) and alternative (b) arrangement of wind bracing at deck level 
Model 4

In this model arrangement of concrete slab expansion joints is altered. The concrete slab of the existing span is divided into two parts - an expansion joint is situated at $1 / 2 \cdot \mathrm{L}_{\mathrm{t}}$. The two parts are meant to deform independently. Model 4 assumes additional expansion joints at $1 / 4 \cdot \mathrm{L}_{\mathrm{t}}$ and $3 / 4 \cdot \mathrm{L}_{\mathrm{t}}$. - slab division into four parts. It is shown in Fig. 8.

For the five described models dead and live loads were considered. Dead load includes weight of railway track, gravel and fittings. Live load includes weight of the load model LM71 of $\mathrm{k}=+2$ class with appropriate dynamic coefficient. Load scheme producing extreme bending moment at midspan has been analysed.

a)

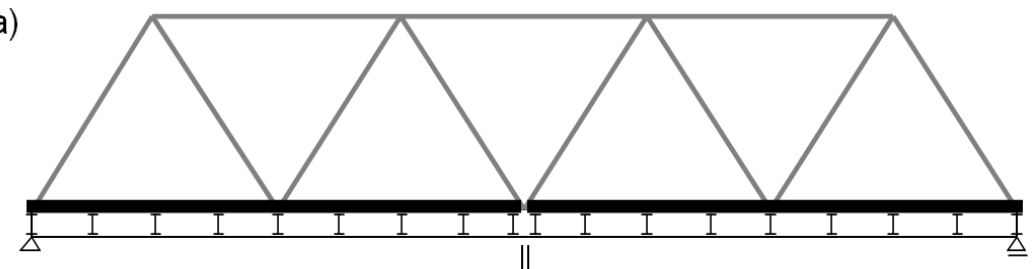

b)

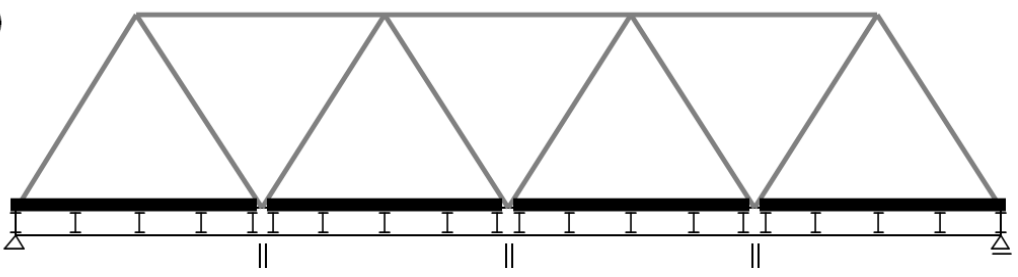

Fig. 8. Existing (a) and alternative (b) arrangement of slab expansion joints (marked with \|)

Transverse shear forces have been calculated for the following cross beams: Pp1, Pp3, Pp5, Pp7, Pp9 (Fig. 4). The forces were computed as the difference of membrane forces in an appropriate shell elements on the both sides of the given cross beam.

\section{RESULTS OF NUMERICAL ANALYSIS}

The values of horizontal shear forces (which are transverse to cross beams and occur at the steel-concrete interface) obtained from the analysed models have been compared.

Extreme values of transverse shear forces obtained for the analysed cross beams are shown in Fig. 9. It can be observed that extreme values of the forces computed for structural alterations applied in the models $1 \div 4$ are in general 
smaller than the values of the respective shear forces obtained for the existing structural arrangement (the model 0). Increase of values of the transverse shear force can be seen in the centre of slab width for the structural alteration used in the model $1(6 \%)$ and near slab edges for the structural alteration used in the model $3(1 \%)$.

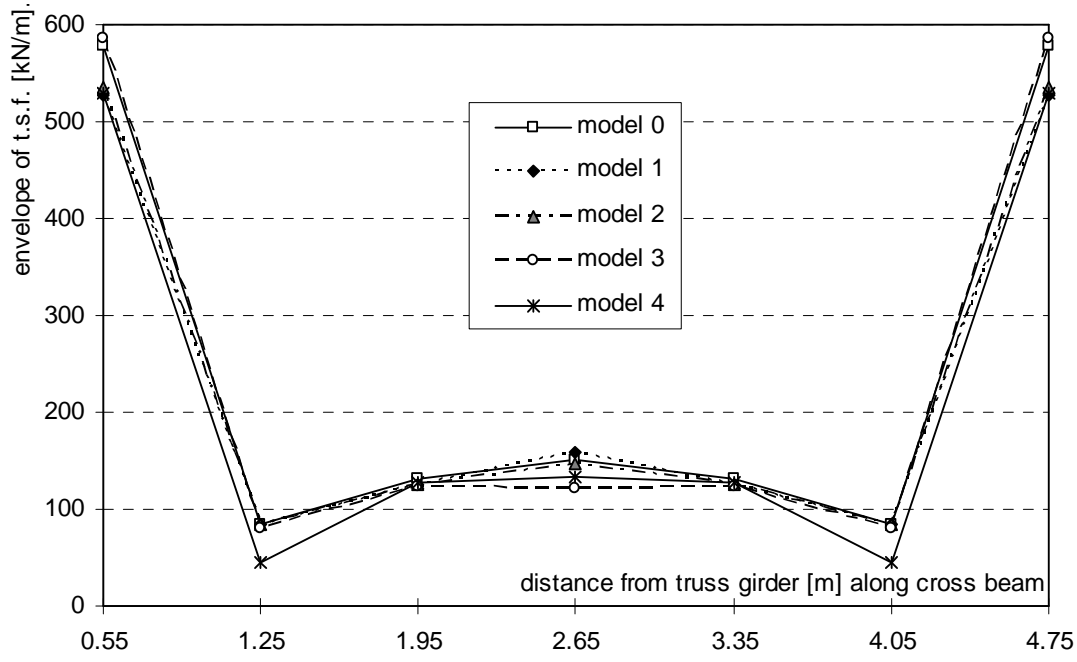

Fig. 9. Extreme values of transverse shear forces (t.s.f.) across concrete slab

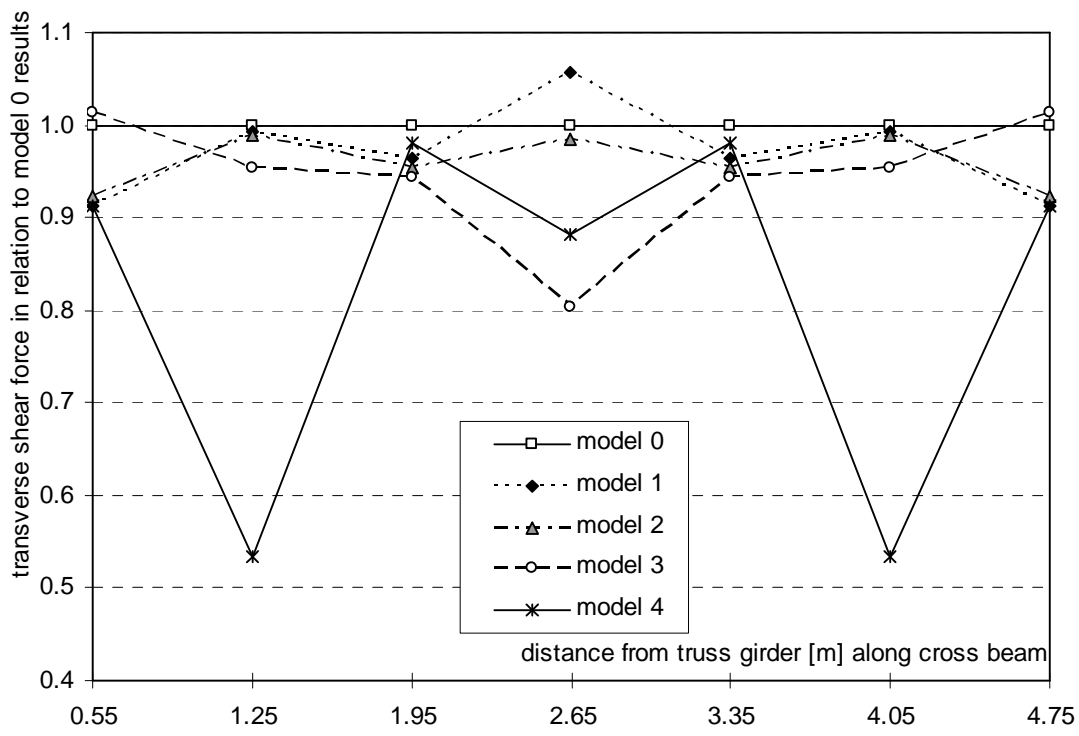

Fig. 10. Relative values of transverse shear forces across concrete slab 
Fig. 10 presents the values of the transverse shear forces from Fig. 9 in relationship to the results obtained for the existing structural arrangement (the model 0). Critical (extreme) values of transverse shear forces occur near the slab side edges. Structural alterations used in the models 1, 2 and 4 provide $\sim 8 \%$ reduction of the force value while the structural alteration used in the model 3 provides $1 \%$ increase. Fig. 10 shows that the most effective, in terms of the reduction of the values of transverse shear force, is the structural alteration applied in the model 4. For this alteration the reduction within the range of $9 \div 47 \%$ was computed. The alteration applied in the model 3 is more effective in the slab centre.

The values of transverse shear forces acting on subsequent cross beams near the side edge of a slab and in the centre of a slab width are given in Fig. 11a and Fig. $11 \mathrm{~b}$ respectively. It can be seen that variations of transverse shear forces in the models $0 \div 3$ are similar. The differences obtained from the model 4 are caused by additional expansion joints. In the case of both existing and altered arrangements of expansion joints the extreme transverse shear forces occur at the cross beam in the middle of the bridge span. Structural alterations applied in the models 1 and 2 provide decrease of values of the transverse shear forces near the side edge of a slab and increase of values of shear forces in the centre of a slab width. The structural alteration applied the model 3 leads to more even distribution of the transverse shear forces in the centre of a slab width along the bridge span.

a)

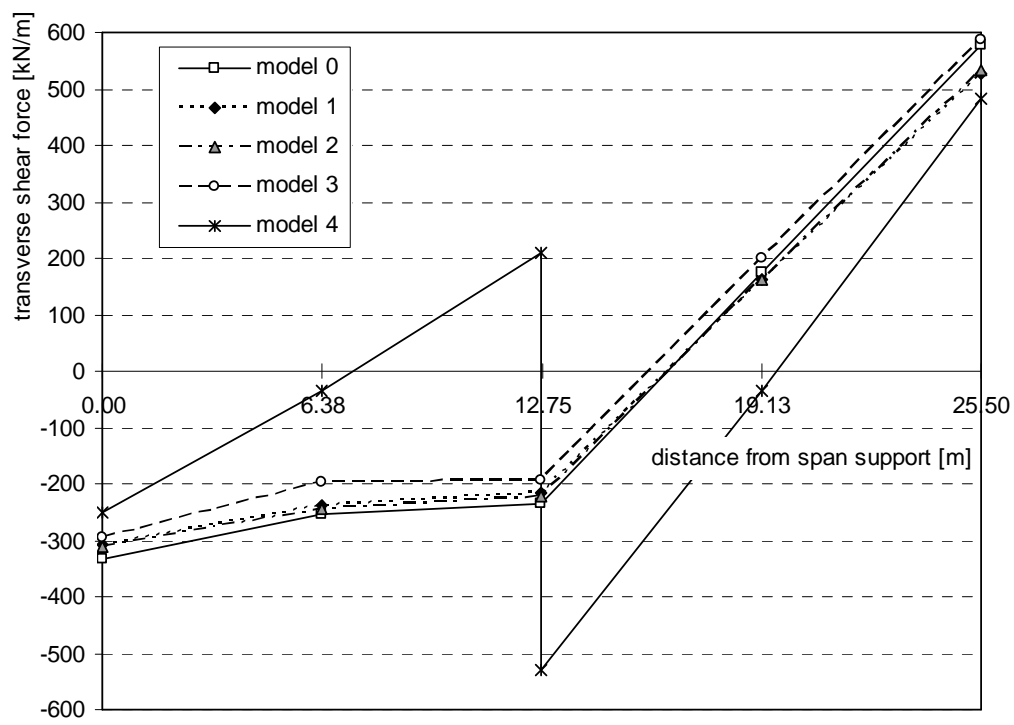




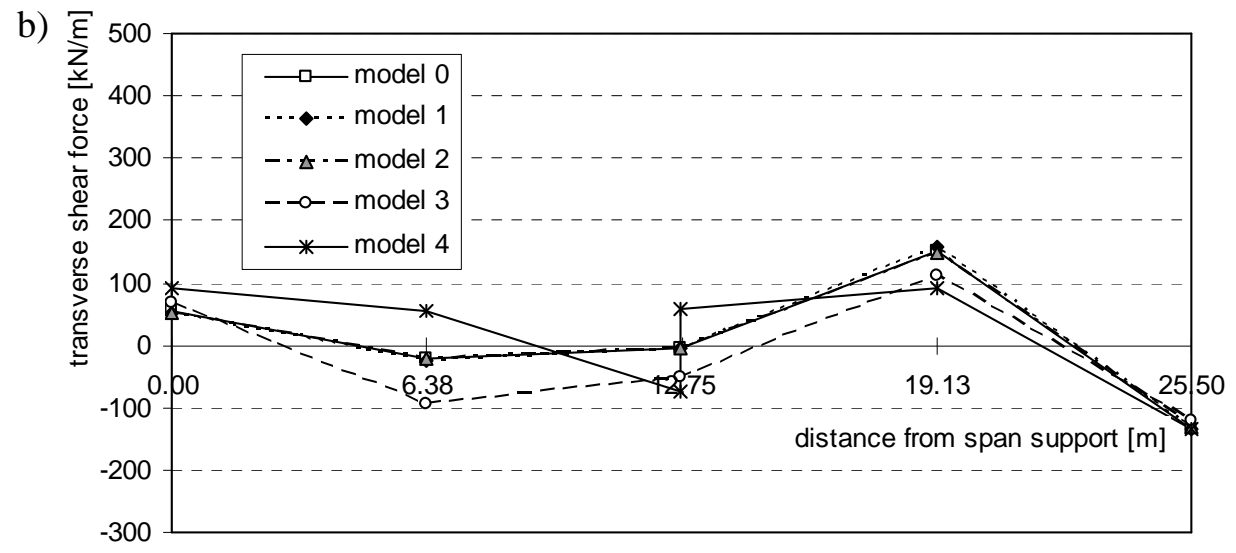

Fig. 11. Values of shear forces transverse to cross beams acting on subsequent cross beams near slab side edge (a) and in the slab width centre (b)

\section{CONCLUSION}

1. In the view of the results of numerical analysis transverse shear forces at the steel-concrete interface in composite deck caused by joint action of the deck and main girders may be reduced due to structural alterations.

2. Examples of structural alterations that reduce the extreme values of shear forces transverse to cross beams are: a) change of distribution of the slab thickness (by changing concrete slab drainage system), b) change of deformability of slab concrete (by changing elastic modulus of concrete), c) change of cross beams kinematic constraints (by changing arrangement of wind bracing at cross beam level), d) change of overall characteristics of joint action of deck and girders (by changing arrangement of deck slab expansion joints).

3. Numerical analyses show that the most effective are methods c) and d). The method c) provides reduction of the extreme transverse shear forces in the middle of the slab width centre (up to 19\%) while the method d) does it near slab edges (up to $9 \%$ ).

4. The methods c) and d), applied in existing railway truss bridges with steelconcrete composite decks, would reduce stress level in cross beams at their connections to truss girders.

\section{REFERENCES}

1. Furtak K., Mosty zespolone, PWN, Warszawa 1999 
2. Hou W., Ye M., Design methods of headed studs for composite decks of through steel bridges in high-speed railway, J. Cent. South Univ. Technol., 18 (2011) 946-952

3. Karlikowski J., Madaj A., Wołowicki W., Mostowe konstrukcje zespolone stalowo-betonowe, WKŁ, Warszawa 2007.

4. Siekierski W., Analiza numeryczna sit rozwarstwiajacych $w$ pomoście zespolonym przęsta kratowego, Inżynieria i Budownictwo, 12 (2011) 674676.

5. Siekierski W., Kolejowe przęsta kratownicowe z pasem sztywnym, Inżynieria i Budownictwo, 2 (2010) 97-99.

6. Siwowski T., Sobala D., Ślęczka L., Analiza przyczyn pękania zespolonej poprzecznicy kratowego mostu wiaduktu kolejowego, konferencja naukowotechniczna „Mosty zespolone”, Kraków 7-9.05.1998, 357-366.

7. Xue D., Liu Y., Yu Z., He J., Static behavior of multi-stud shear connectors for steel-concrete composite bridge, Journal of Constructional Steel Research, 74 (2012) 1-7.

8. Ye M., Huang Q., Wu Q., Analysis of steel-concrete composite structure with overlap slab of Xingguang bridge, J. Cent. South Univ. Technol., 14 (2007) 120-124.

\section{KONSTRUKCYJNE ASPEKTY KOLEJOWYCH MOSTÓW KRATOWNICOWYCH DECYDUJĄCE O POPRZECZNYCH SIŁACH ROZWARSTWIAJĄCYCH W POMOSTACH ZESPOLONYCH}

\section{Streszczenie}

Współpraca pomostu zespolonego z kratownicowymi dźwigarami głównymi wzbudza poprzeczne siły rozwarstwiające $\mathrm{w}$ styku belek poprzecznych $\mathrm{i}$ betonowej płyty pomostowej. W pracy przeanalizowano numerycznie wpływ niektórych aspektów konstrukcyjnych przęsła kratownicowego mostu kolejowego na poprzeczne siły rozwarstwiające w pomoście zespolonym. Wykorzystano model obliczeniowy zweryfikowany wynikami badań przęsła pod próbnym obciążeniem. Analizowano wpływ czterech modyfikacji układu istniejącego, uwzględnionego w modelu pierwotnym. Były to m.in.: odmienny układ stężeń wiatrowych (,X” zamiast „, poprzecznych przerw dylatacyjnych $\mathrm{w}$ płycie pomostowej (trzy $\mathrm{w}$ przęśle zamiast jednej). Stwierdzono, że zmiana układu stężeń wiatrowych wywołuje największą redukcję ekstremalnych poprzecznych sił rozwarstwiających w środku szerokości płyty, natomiast zwiększenie liczby poprzecznych przerw dylatacyjnych płyty powoduje największą redukcję poprzecznych sił rozwarstwiających w sąsiedztwie bocznych krawędzi płyty. Zabiegi zmiany układu stężeń wiatrowych w poziomie pomostu oraz 
zwiększenia liczby dylatacji płyty pomostu, zastosowane w istniejących kolejowych mostach kratownicowych z pomostem zespolonym, spowodują także redukcję wytężenia poprzecznic $\mathrm{w}$ połączeniach $\mathrm{z}$ dźwigarami głównymi.

Słowa kluczowe: stalowo-betonowy pomost zespolony, siły ścinające, most kratownicowy

Editor received the manuscript: 4.07.2014 